\section{RSP}

http://www.rsp.fsp.usp.br/
Revista de Saúde Pública

\title{
User satisfaction in the spanish health system: trend analysis
}

\author{
Víctor Pérez-Cantól iD, Loreto Maciá-Soler"I iD, Víctor M González-Chordá"I iD \\ I Universidad de Alicante. Departamento de Enfermería. Alicante, AL, España \\ " Univesidad de Alicante. Unidad Científica de Innovación Empresarial "Ars Innovatio". Alicante, AL, España \\ III Universitat Jaume I. Departamento de Enfermería. Castellón, CS, España
}

\begin{abstract}
OBJECTIVE: To analyze the trend of opinion and satisfaction indicators of the Spanish national health system from 2005 to 2017

METHODS: Ecological study of time series analyzing the trend of eight indicators of opinion and satisfaction on the Spanish national health system and its autonomous communities from 2005 to 2017. The data was obtained from the Ministry of Health, Social Services and Equality and from the Health Barometer. The Prais-Winsten regression method was used.
\end{abstract}

RESULTS: A static tendency was observed in the perception of users on how the health system works (APC $=1.898,95 \% \mathrm{CI}-0.954-4.751)$ and decreasing opinion on the improvement of primary care (APC $=-0.283$; 95\% CI $-0.335--0.121$ ), specialized (APC $=-0.241$, 95\%CI $-0.74--0.109$ ) and hospitalization (APC $=-0.171,95 \% \mathrm{CI}-0.307--0.036$ ). Satisfaction with knowledge and follow-up by the family doctor and pediatrician showed an increasing trend (APC $=7.939,95 \%$ CI $3.965-11.914$ ). Satisfaction with medical and nursing professionals was static. No large differences were observed in the trends of the indicators studied in the autonomous communities.

CONCLUSIONS: A negative trend was observed in the opinion of the Spanish national health system users. Financing, human resources, quality management systems and differences in the autonomous communities may be some of the causes.

Correspondence:

Víctor M González-Chordá Universitat Jaume I

Departamento de Enfermería

Avda Sos Baynat s/n

12071. Castellón, CS, España

vchorda@uji.es

Received: Feb 15, 2019

Approved: Apr 25, 2019

How to cite: Pérez-CantóV, Maciá-Soler L, González-Chordá

VM. User satisfaction in the

Spanish health system: trend analysis. Rev Saude Publica.

2019;53:87.

Copyright: This is an open-access article distributed under the terms of the Creative Commons Attribution License, which permits unrestricted use, distribution, and reproduction in any medium, provided that the original author and source are credited.

DESCRIPTORS: Patient Satisfaction. National Health Systems. Quality of Health Care. Health Services Research. 


\section{INTRODUCTION}

Health systems aim to improve the health of citizens through healing, prevention and rehabilitation. However, they are influenced by political, social, cultural and economic factors of each country. Quality management systems ensure the intrinsic and noticed quality of the services. The intrinsic quality is focused on the design, execution and assessment of processes. The noticed quality aims at the evaluation and satisfaction of the users ${ }^{1}$.

Satisfaction, understood as the ability to generate a positive experience for users and the population in contact with health services, has been widely studied since the 1960s despite its subjective nature ${ }^{2}$. Governments and policy analysts have used patient satisfaction as an approach to assess the performance of health systems. The institutions regularly monitor the satisfaction of their patients and develop strategies to improve quality and achieve a better position in the market. The information about satisfaction allows us to predict, among other things, therapeutic compliance and the possible return before a new episode. The two strategic points and their result directly influences the costs, profitability and sustainability of the organizations ${ }^{3}$.

The evaluation of user satisfaction is not exempt from methodological problems. Satisfaction is influenced by patient characteristics such as age, gender, marital status, education, income level or health status ${ }^{4,5}$. Older people are usually more satisfied, and the dissatisfaction increases as their health worsen ${ }^{6}$. In addition, custom-made measuring instruments are commonly used, validated in a few cases?

The influence of socioeconomic factors should also be considered. The recent economic crisis in Europe has put great pressure on health systems. Some countries took restrictive measures such as reducing the service portfolio and expenses on medication or cutting personnel and salaries. These measures can increase social inequalities in healthcare coverage and have a negative impact on the safety and satisfaction of users ${ }^{8}$.

There are ways to control spending and improve profitability based on the implementation of quality management systems and on the improvement of care outcomes, for example, hospital mortality, reduction of stays, readmissions or patient satisfaction, among others. Therefore, patient satisfaction has been established as a key indicator of outcome to evaluate the quality and efficiency of health services, coinciding with the strategic lines of the World Health Organization (WHO) ${ }^{9}$.

The national health system is launched in Spain, 1986, after the enactment of the General Health Law ${ }^{10}$. Some main characteristics are the right of every citizen to health, public financing and provision of services that guarantee the quality of care, with decentralized health system in autonomous communities.

The process of decentralization of competencies ended in 2001. In 2003, the Law of Cohesion and Quality of the National Health System was enacted to guarantee citizen participation, quality and equity of assistance in the national territory. This law establishes the fundamental principles on quality of care and the development of tools such as the portfolio of services, training and development of professionals, research, unique digital clinical history, use of guides, protocols and indicators, or a single information system ${ }^{11}$. However, it does not specify the need to establish a quality management system for the entire national territory or in its autonomous communities. After 15 years since its implementation, some of the main problems are: lack of equity in spending and financing, the health level of citizens, accessibility to health services and use of resources ${ }^{12}$.

Providing information related to quality is an aspect of public health interest. Improving health systems and, therefore, examining trends in user satisfaction can make it possible to evaluate the impact of the health policies adopted, observing the influence of these changes on the opinions, experiences and attitudes of citizens regarding health care ${ }^{13}$. Trend studies 
in Spain are limited and there is no trend analysis of indicators related to the satisfaction of the healthcare system users.

This study aimed to analyze the trend of the opinion and satisfaction indicators of the Spanish National Health System between 2005 and 2017.

\section{METHODS}

Ecological study of time series that analyzed the satisfaction trend of users of the Spanish national health system and its autonomous communities, between 2005 and 2017.

The variables were satisfaction with how the health system works, with information and with the care and attention received, in addition to the improvement noticed by the users. For this, the trend of eight indicators of opinion and user satisfaction on the Spanish national health system and its autonomous communities was analyzed. Three indicators were obtained from the series of Key Indicators of the National Health System (NHS) and its autonomous communities, through the Health Information System of the Ministry of Health, Social Services and Equality ${ }^{14}$, and five indicators of the Health Barometer ${ }^{15}$ (Table).

The series of Key Indicators make it possible to observe changes and trends since 1990. Currently, the complete list amounts to 247 indicators (accessibility, health status, resources, spending, security and satisfaction, among others). Indicators with standardized definitions and international use are studied, which are accessible for consultation and analysis in a single repository. These indicators are calculated by obtaining data from different sources with broad population coverage, such as the Minimum Basic Data Set for hospital discharges, the Primary Care Information System, intercensal statistics from the National Institute of Statistics or the National Health Survey, among others ${ }^{14}$.

The Health Barometer is an opinion study, conducted annually, carried out since 1993 by the same ministry in collaboration with the Spanish Sociological Research Center. It is designed to know the degree of citizen satisfaction with public health services, the impact of measures linked to health policies, the level of knowledge of citizens and public opinion on these policies. The information is collected through questionnaires, with a multi-stage

Table. Satisfaction indicators selected to carry out the study. Spain, 2018.

\begin{tabular}{|c|c|}
\hline Indicator & Formula/question \\
\hline \multicolumn{2}{|l|}{ Key Indicators } \\
\hline $\begin{array}{l}\text { Satisfaction with the operation of the } \mathrm{NHS}^{\mathrm{a}} \\
\text { Satisfaction with the knowledge of the clinical history and the monitoring } \\
\text { of their health problems by the family doctor and the pediatrician } \\
\text { batisfaction with the information received in the specialist } \\
\text { doctor's appointment }^{\mathrm{a}}\end{array}$ & $\begin{array}{l}\text { Ratings average of the satisfaction } \\
\text { degree collected on a Likert scale } \\
\text { of } 1 \text { ("very dissatisfied") to } 10 \\
\text { ("totally satisfied"). }\end{array}$ \\
\hline \multicolumn{2}{|l|}{ Health barometer } \\
\hline $\begin{array}{l}\text { Satisfaction with care and attention by medical staff } \\
\text { Satisfaction with the care and attention by the Nursing staff }\end{array}$ & $\begin{array}{l}\text { Ratings average of the satisfaction } \\
\text { degree collected on a Likert scale } \\
\text { of } 1 \text { ("totally unsatisfactory") to } 10 \\
\text { ("totally satisfactory"). }\end{array}$ \\
\hline $\begin{array}{l}\text { Percentage of respondents who believe that primary care has improved } \\
\text { Percentage of respondents who believe that specialized care } \\
\text { consultations have improved } \\
\text { Percentage of respondents who believe that hospitalization has improved }\end{array}$ & $\begin{array}{l}\text { In your opinion, has each of the } \\
\text { following health care services } \\
\text { improved, worsened or remains the } \\
\text { same over the last five years? }\end{array}$ \\
\hline
\end{tabular}

NHS: National Health System

a Last year of available data: 2017.

b Last year of available data: 2013.

c Last year of available data: 2016. 
sample design, stratified by conglomerates, with random selection of the sampling units, and a total of 7,800 annual surveys ${ }^{15}$.

According to the definitions of the indicators in the NHS Information System (Key Indicator) or the Health Barometer, the indicators included in this study are estimated by means, adding the satisfaction degree assessments, divided by number of individuals surveyed, except for the last three indicators that are estimated as percentages.

Data have been included since 2005, because in previous years the series were interrupted, and data were not available in the indicators analyzed. The last year was 2017, except for an indication that the historical series ended in 2013 or 2016, according to the availability of data from the health information system. The autonomous cities of Ceuta and Melilla were excluded, since the complete historical series were not available.

The estimation of the trends was based on the calculation of the annual percentage change (Annual Percent Change - APC) and its 95\% confidence intervals (95\%CI). The Praes-Wisten regression method was used for the analysis of time series of quantitative data. Thus, a global trend was obtained for a certain period and was determined as increasing ( $95 \% \mathrm{CI}$ is positive and does not include the value 0$)$, static $(95 \% \mathrm{CI}$ includes value 0$)$, or decreasing ( $95 \% \mathrm{CI}$ is negative and does not include the value 0 ). The analysis was performed using the Stata 14.0 program.

The study was carried out with aggregate data obtained from public sources, being openly accessible for consultation and exploitation. For this reason, the approval of the study was not requested by an ethics and research committee.

\section{RESULTS}

The degree of satisfaction with how the health system works increased from 6.25 in 2005 to 6.68 in 2017, showing a static trend in all the communities and in the whole country, except for Madrid, that showed an increasing trend (APC $=7.451$; 95\%CI: 0.433-14.470). Asturias was the only place that showed a negative annual variation, although it was not significant (Table 1). The information received in the specialist physician appointment was static in all Spain (APC $=2.585,95 \%$ CI -2.078-2.085) and in the autonomous communities, except for the Canary Islands with a significant increasing trend (APC $=0.942,95 \% \mathrm{CI}-0.200-6.337$ ). There was a negative non-significant annual variation in the Baleares, Asturias, Rioja, Extremadura, and Cataluña.

The trend in satisfaction with the knowledge of the clinical history and follow-up by the family doctor and pediatrician was increasing in all Spain (APC $=7.939,95 \% \mathrm{CI} 3.965-11.914)$, increasing by 0.6 points in the period. Madrid, Andalucía, Navarra, Canarias and Galicia showed a significant increasing trend. In the rest of the autonomous communities, the trend was static. The communities that showed a decreasing annual variation were Baleares and Asturias (Table 2).

The satisfaction of the users with the nursing staff showed a static trend in all Spain $(\mathrm{APC}=1.898,95 \% \mathrm{CI}-0.954-4.751)$ and in all the autonomous communities. Similarly, the attention by the medical staff was static (APC $=3.227$, 95\%CI -7.076-13.531), as were in all the autonomous communities, except for Asturias, which showed a decreasing trend $(\mathrm{APC}=-10.486$; $95 \% \mathrm{CI}-12.798--8.174)$ with a decrease of more than 10 points (Table 3$)$.

We observed a decreasing trend in the improvement perceived by users in primary care services in all Spain (APC $=-0.238,95 \% \mathrm{CI}-0.335--0.121$ ), as well as in five communities (Asturias, Cantabria, Andalucía, Cataluña and Madrid). The percentage of users who believe that the attention in specialized consultations has improved showed a decreasing trend in Spain (APC $=-0.241,95 \%$ CI $-0.74--0.109$ ) and four communities (Basque Country, Asturias, Andalucía and Cantabria); the others were static. Likewise, a decreasing trend was 
Table 1. Degree of satisfaction with how the public health system works. Spain, 2018

\begin{tabular}{|c|c|c|c|c|c|}
\hline CCAA & 2005 & 2017 & APC & $95 \% \mathrm{Cl}$ & Trend \\
\hline Andalucía & 6.14 & 6.27 & 1.031 & $-4.239-6.302$ & Static \\
\hline Aragón & 6.41 & 7.29 & 2.210 & $-2.114-6.536$ & Static \\
\hline Asturias & 7.26 & 7.22 & -0.239 & $-3.338-2.859$ & Static \\
\hline Baleares & 5.83 & 6.98 & 0.845 & $-2.560-4.252$ & Static \\
\hline Canary Islands & 5.37 & 6.10 & 1.014 & $-1.749-3.778$ & Static \\
\hline Cantabria & 6.33 & 7.35 & 1.542 & $-1.884-4.969$ & Static \\
\hline Castilla and León & 6.40 & 7.07 & 0.735 & $-1.677-3.148$ & Static \\
\hline Cataluña & 5.96 & 6.51 & 1.012 & $-3.033-5.058$ & Static \\
\hline Extremadura & 6.30 & 6.61 & 0.726 & $-2.176-3.629$ & Static \\
\hline Galicia & 5.56 & 6.49 & 2.302 & $-0.922-5.527$ & Static \\
\hline La Mancha & 6.61 & 6.65 & 0.388 & $-2.036-2.813$ & Static \\
\hline Madrid & 6.10 & 6.82 & 7.451 & $0.433-14.470$ & Increasing \\
\hline Murcia & 6.01 & 7.10 & 1.475 & $-1.455-4.405$ & Static \\
\hline Navarra & 6.71 & 7.06 & 1.246 & $-2.453-4.946$ & Static \\
\hline Basque Country & 6.51 & 7.33 & 1.265 & $-2.348-4.879$ & Static \\
\hline Rioja & 6.56 & 6.99 & 0.090 & $-4.924-5.106$ & Static \\
\hline Valencia & 6.12 & 6.71 & 1.852 & $-2.340-6.045$ & Static \\
\hline Spain & 6.25 & 6.68 & 1.898 & $-0.954-4.751$ & Static \\
\hline
\end{tabular}

CCAA: autonomous communities; APC: annual percent change

observed in hospitalization services in Spain (APC $=-0.171,95 \% \mathrm{CI}-0.307--0.036)$ and in three autonomous communities (Murcia, Asturias and Andalucía). No community showed an increasing trend in the percentage of respondents who assessed whether the attention in these three services had improved in the last five years.

\section{DISCUSSION}

In general, there was a static trend in Spain and most of its autonomous communities in the indicators: degree of satisfaction with how the public health system works, information received by the specialist doctor and knowledge of clinical history, as well as follow-up by the family physician and pediatrician. There are few studies of trends in satisfaction at national and international levels and there is little research that links trends to improvements made based on patient satisfaction ${ }^{16}$. However, the cases with an increasing tendency on the indicators linked to the development of the digital clinical history of the NHS in Spain are related to improvements identified by the users when they go to a health center looking for information about their illness and the order in their documentation ${ }^{17}$.

Analysts argue that more financing does not necessarily lead to better satisfaction and cannot explain a large part of the difference in satisfaction ratings between countries ${ }^{18,19}$. A study conducted in France ${ }^{18}$ with more than 10,000 patients showed that they were satisfied with their hospital stay despite reductions in hospital costs. In Spain, an analysis of trends on specialized care indicators ${ }^{19}$ showed an increase of 9.5 points on spending, with a decreasing trend of users' satisfaction for these services and worse health outcomes (increase of infections and in-hospital mortality).

The latest annual report of the Spanish national health system ${ }^{20}$ shows how some autonomous communities with high healthcare costs (Basque Country, Extremadura, Navarra, Murcia, Asturias and Cantabria) presented positive ratings of users in most of the indicators, while Baleares and Andalucía showed worse results in most indicators, coinciding with lower health expenses. The heterogeneity of the autonomous communities in financing can influence the results of user opinion. In addition, a north-south gradient 
Table 2. Degree of satisfaction with the information received in the specialist and family doctor appointment about their health. Spain, 2018

\begin{tabular}{|c|c|c|c|c|c|c|}
\hline CCAA & & 2005 & $2017^{*}$ & APC & $95 \% \mathrm{Cl}$ & Trend \\
\hline \multirow{2}{*}{ Andalucía } & Specialist & 7.26 & 7.12 & 0.364 & $-5.344-5.250$ & Static \\
\hline & Physician & 6.97 & 7.59 & 6.183 & 2.799-9.567 & Increasing \\
\hline \multirow{2}{*}{ Aragón } & Specialist & 7.16 & 7.71 & 1.248 & $-3.314-3.403$ & Static \\
\hline & Physician & 7.82 & 8.18 & 1.441 & $-1.953-4.835$ & Static \\
\hline \multirow{2}{*}{ Asturias } & Specialist & 8.02 & 7.24 & -0.881 & $-1.622-4.118$ & Static \\
\hline & Physician & 7.44 & 7.31 & -0.034 & $-2.638-2.568$ & Static \\
\hline \multirow{2}{*}{ Baleares } & Specialist & 7.32 & 6.8 & -2.711 & $-4.044-4.773$ & Static \\
\hline & Physician & 7.00 & 7.29 & -0.702 & $-3.226-1.821$ & Static \\
\hline \multirow{2}{*}{ Canary Islands } & Specialist & 6.32 & 6.84 & 0.942 & $0.200-6.337$ & Increasing \\
\hline & Physician & 6.87 & 7.42 & 5.202 & $2.236-8.168$ & Increasing \\
\hline \multirow{2}{*}{ Cantabria } & Specialist & 7.22 & 7.65 & 1.479 & $-3.484-4.951$ & Static \\
\hline & Physician & 7.63 & 7.76 & 0.555 & $-3.261-4.372$ & Static \\
\hline \multirow{2}{*}{$\begin{array}{l}\text { Castilla and } \\
\text { León }\end{array}$} & Specialist & 7.12 & 7.35 & 0.423 & $-2.745-6.207$ & Static \\
\hline & Physician & 7.24 & 7.65 & 1.504 & $-3.262-6.272$ & Static \\
\hline \multirow{2}{*}{ Cataluña } & Specialist & 6.87 & 6.95 & -0.046 & $-2.255-5.214$ & Static \\
\hline & Physician & 6.67 & 7.4 & 2.968 & $-2.179-8.117$ & Static \\
\hline \multirow{2}{*}{ Extremadura } & Specialist & 7.59 & 7.56 & -0.273 & $-6.633-1.210$ & Static \\
\hline & Physician & 7.53 & 7.46 & 2.044 & $-4.223-8.313$ & Static \\
\hline \multirow{2}{*}{ Galicia } & Specialist & 6.08 & 7.14 & 2.879 & $-1.463-1.144$ & Static \\
\hline & Physician & 6.46 & 7.33 & 4.063 & $0.837-7.289$ & Increasing \\
\hline \multirow{2}{*}{ La Mancha } & Specialist & 7.17 & 7.48 & 0.888 & $-2.465-4.192$ & Static \\
\hline & Physician & 7.30 & 7.96 & 3.199 & $-0.920-7.319$ & Static \\
\hline \multirow{2}{*}{ Madrid } & Specialist & 6.68 & 7.08 & 0.863 & $-0.945-6.705$ & Static \\
\hline & Physician & 7.03 & 7.47 & 8.959 & $5.640-12.279$ & Increasing \\
\hline \multirow{2}{*}{ Murcia } & Specialist & 7.06 & 8.07 & 3.268 & $-4.695-9.865$ & Static \\
\hline & Physician & 7.15 & 7.62 & 1.094 & $-3.678-5.868$ & Static \\
\hline \multirow{2}{*}{ Navarra } & Specialist & 7.09 & 7.42 & 0.044 & $-2.796-4.572$ & Static \\
\hline & Physician & 7.00 & 8.29 & 5.771 & $4.948-6.594$ & Increasing \\
\hline \multirow{2}{*}{ Basque Country } & Specialist & 6.86 & 7.21 & 0.733 & $-5.287-4.740$ & Static \\
\hline & Physician & 7.03 & 7.55 & 0.587 & $-2.971-4.146$ & Static \\
\hline \multirow{2}{*}{ Rioja } & Specialist & 7.64 & 7.2 & -0.477 & $-3.507-1.744$ & Static \\
\hline & Physician & 7.54 & 8.04 & 1.278 & $-1.923-4.481$ & Static \\
\hline \multirow{2}{*}{ Valencia } & Specialist & 6.57 & 7.26 & 1.730 & $-3.150-2.195$ & Static \\
\hline & Physician & 6.67 & 7.46 & 2.637 & $-1.903-7.178$ & Static \\
\hline \multirow{2}{*}{ Spain } & Specialist & 6.91 & 7.19 & 2.585 & $-2.078-2.085$ & Static \\
\hline & Physician & 6.96 & 7.56 & 7.939 & $3.965-11.914$ & Increasing \\
\hline
\end{tabular}

CCAA: autonomous communities; APC: annual percent change

* The data related to the satisfaction of the family doctor are from 2013

was observed, since the best results in the indicators studied were in the northern half of the country and the worst in the south. This gradient has already been mentioned in previous research ${ }^{21}$, related to the decline in public spending on health and an increase in inequalities between autonomous communities.

A decreasing trend was observed in the percentage of patients who believe that primary care, specialized care consultations and hospitalization, three pillars of the health system, have improved. The hospitalization results coincide with other trend studies in France ${ }^{18}$ and Germany $^{22}$. This suggests that aspects related to quality such as information, comfort and agility of systems increasingly influence the satisfaction of users ${ }^{23}$.The main problems in primary care may be underfunding and the heterogeneity caused by the decentralization of competencies ${ }^{24}$. However, the possible strategies to be implemented must be well-thought. 
Table 3. Degree of satisfaction with the care received by nursing and medicine professionals. Spain. 2018.

\begin{tabular}{|c|c|c|c|c|c|c|}
\hline CCAA & & 2005 & 2016 & APC & $95 \% \mathrm{Cl}$ & Trend \\
\hline \multirow{2}{*}{ Andalucía } & Nursing & 7.51 & 7.28 & 0.108 & $-4.407-4.625$ & Static \\
\hline & Medicine & 7.46 & 7.15 & -0.110 & $-4.374-4.153$ & Static \\
\hline \multirow{2}{*}{ Aragón } & Nursing & 7.85 & 8.16 & 1.563 & $-3.377-6.504$ & Static \\
\hline & Medicine & 7.86 & 8.25 & 1.250 & $-2.501-5.002$ & Static \\
\hline \multirow{2}{*}{ Asturias } & Nursing & 8.25 & 7.49 & -1.069 & $-3.682-1.543$ & Static \\
\hline & Medicine & 8.19 & 7.36 & -10.486 & $-12.798--8.174$ & Decreasing \\
\hline \multirow{2}{*}{ Baleares } & Nursing & 7.29 & 7.82 & 0.036 & $-3.197-3.270$ & Static \\
\hline & Medicine & 7.15 & 7.52 & -0.296 & $-3.447-2.853$ & Static \\
\hline \multirow{2}{*}{ Canary Islands } & Nursing & 6.90 & 7.57 & 0.771 & $-3.325-4.868$ & Static \\
\hline & Medicine & 6.70 & 7.36 & 1.162 & $-3.327-5.652$ & Static \\
\hline \multirow{2}{*}{ Cantabria } & Nursing & 7.60 & 8.04 & 1.690 & $-4.130-7.510$ & Static \\
\hline & Medicine & 7.61 & 7.95 & 0.857 & $-3.040-4.755$ & Static \\
\hline \multirow{2}{*}{ Castilla and León } & Nursing & 7.08 & 7.40 & 1.939 & $-3.715-7.593$ & Static \\
\hline & Medicine & 7.47 & 7.55 & 1.380 & $-4.459-7.219$ & Static \\
\hline \multirow{2}{*}{ Cataluña } & Nursing & 7.39 & 7.46 & 1.219 & $-4.562-7.001$ & Static \\
\hline & Medicine & 7.24 & 7.23 & 0.288 & $-4.814-5.391$ & Static \\
\hline \multirow{2}{*}{ Extremadura } & Nursing & 7.66 & 7.53 & 0.415 & $-3.552-4.383$ & Static \\
\hline & Medicine & 7.60 & 7.53 & 0.151 & $-3.989-4.291$ & Static \\
\hline \multirow{2}{*}{ Galicia } & Nursing & 6.39 & 7.28 & 1.279 & $-1.939-4.499$ & Static \\
\hline & Medicine & 6.28 & 7.13 & 1.252 & $-2.262-4.768$ & Static \\
\hline \multirow{2}{*}{ La Mancha } & Nursing & 7.56 & 7.68 & 0.142 & $-3.511-3.797$ & Static \\
\hline & Medicine & 7.18 & 7.22 & -0.306 & $-3.996-3.384$ & Static \\
\hline \multirow{2}{*}{ Madrid } & Nursing & 7.14 & 7.58 & 2.342 & $-3.964-8.650$ & Static \\
\hline & Medicine & 6.98 & 7.48 & 1.251 & $-3.216-5.719$ & Static \\
\hline \multirow{2}{*}{ Murcia } & Nursing & 6.96 & 7.47 & 1.505 & $-2.687-5.698$ & Static \\
\hline & Medicine & 6.92 & 7.66 & 2.699 & $-1.658-7.058$ & Static \\
\hline \multirow{2}{*}{ Navarra } & Nursing & 7.67 & 8.00 & 0.816 & $-2.933-4.565$ & Static \\
\hline & Medicine & 7.55 & 7.85 & 0.625 & $-2.668-3.918$ & Static \\
\hline \multirow{2}{*}{ Basque Country } & Nursing & 7.36 & 7.87 & 4.188 & $-1.835-10.218$ & Static \\
\hline & Medicine & 7.14 & 7.65 & 3.531 & $-2.631-9.694$ & Static \\
\hline \multirow{2}{*}{ Rioja } & Nursing & 8.16 & 7.75 & -0.458 & $-3.543-2.626$ & Static \\
\hline & Medicine & 7.93 & 7.75 & 0.006 & $-3.867-3.879$ & Static \\
\hline \multirow{2}{*}{ Valencia } & Nursing & 7.02 & 7.20 & 0.654 & $-5.079-6.389$ & Static \\
\hline & Medicine & 6.96 & 7.25 & 1.127 & $-4.766-7.021$ & Static \\
\hline \multirow{2}{*}{ Spain } & Nursing & 7.30 & 7.48 & 1.898 & $-0.954-4.751$ & Static \\
\hline & Medicine & 7.20 & 7.37 & 3.227 & $-7.076-13.531$ & Static \\
\hline
\end{tabular}

CCAA: autonomous communities; APC: annual percent change

A study conducted in Finland between 1998 and 2011 showed that, despite government reforms, patients were less satisfied with primary care, especially with accessibility and continuity of care $^{25}$.

On the other hand, satisfaction with nursing professionals and physicians in all Spain showed a static trend, despite the increasing trend of nursing and medical professionals in recent years ${ }^{19}$. Autonomous communities with a high degree of satisfaction in relation to nursing and medical professionals had the highest rates of professionals ${ }^{20}$, observing the same north-south gradient. The influence of the rate of professionals on the quality of care and satisfaction is addressed by various authors, although no studies have been identified at national level related to medicine or nursing.

Spain has a medical rate of 3.8 for every thousand inhabitants in its NHS (the European average is 3.5), ranking seventh among the countries with more doctors in Europe. The 
rate of nurses in Spain is 3.5 and the European average of 8.2, being the fifth country with the lowest rate of nurses ${ }^{20}$. Studies conducted in Europe ${ }^{26}$ and China ${ }^{27}$ show that hospitals with low nurse/patient ratios obtain better results on patients and professionals, suggesting that satisfaction with nursing care is an important index to predict patient satisfaction.

Quality management systems and accreditation of institutions are usually linked to the satisfaction of users and quality of care. On the one hand, studies ${ }^{28}$ argue a strong relationship between satisfaction with safety measures, reducing complications such as pressure ulcer and infections. In contrast, a study in 73 hospitals in Germany ${ }^{29}$, with more than 37,000 patients, concluded that accreditation is not linked to a better quality of care as noticed by the patient. Hospital accreditation represents a step towards total quality management but may not be a key factor for the care quality.

A study carried out in 27 European Union member states between $2009-2013^{30}$ on quality and safety perception shows that the changes introduced in health systems during the recession have raised concerns about safety among the population. Despite increasing global spending, European citizens are increasingly concerned about their experience within the health system. Patient satisfaction continues a pending issue in the quality of care management systems.

The results should be carefully considered. It is an ecological study that uses aggregate data in its analysis, being possible the presence of biases, such as the ecological fallacy. However, these studies are widely used designs to study the trend of indicators. Other variables such as age, educational level or level of income that are considered social determinants of health and that can influence the level of satisfaction have not been considered. On the other hand, the results of this time series can be influenced by an economic crisis that has meant an important disinvestment in the health system, with repercussions on the population's health ${ }^{31}$. However, the number of years included is limited to assess the possible impact that recent events such as the economic crisis have had on users' satisfaction. Despite this, the results are important since they show that indicators of user satisfaction can be considered valid tracers to monitor changes, along with other outcome indicators such as mortality.

In conclusion, a static tendency was observed in the perception of users about how the public health system works. The decreasing trend in the percentage of patients who consider that the assistance has improved in primary care, specialized care and hospitalization during the observed period was highlighted. Regarding the satisfaction with medical and nursing professionals, the trend was static. The only indicator that showed a growing trend was the degree of satisfaction with knowledge and follow-up of health problems by the specialist physician and pediatrician. No large differences were observed in the trends of the indicators studied in the autonomous communities.

Factors such as investment in health, human resources, quality management systems and accreditation, added to the heterogeneity in the autonomous communities, can influence the satisfaction indicators of the Spanish national health system. Research with more complex than ecological designs is necessary to determine the impact of these factors on user satisfaction. The challenge is to achieve a better understanding of underlying factors that cause differences in satisfaction, to focus improvement strategies in areas of dissatisfaction where the needs and patients' expectations are not covered.

\section{REFERENCES}

1. Maciá Soler ML, Moncho Vasallo J. Sistema nacional de salud español: características y análisis. Enferm Glob. 2007;6(1):\#10. https://doi.org/10.6018/eglobal.6.1.256

2. Donabedian A. Evaluating the quality of medical care. Milbank Q. 2005;83(4):691-729. https://doi.org/10.1111/j.1468-0009.2005.00397.x 
3. Monteagudo O, Navarro C, Alonso P, Casas R, Rodríguez L, Gracia J, et al. Aplicación hospitalaria del Servqhos: factores asociados a la satisfacción e insatisfacción. Rev Calid Asist. 2003;18(5):263-7. https://doi.org/10.1016/S1134-282X(03)77619-2

4. Mira JJ, Aranaz J. La satisfacción del paciente como una medida del resultado de la atención sanitaria. Med Clin (Barc). 2000;114 Supl 3:26-33.

5. Pérez-Romero S, Gascón-Cánovas JJ, Salmerón-Martínez D, Parra-Hidalgo P, Monteagudo-Piqueras $\mathrm{O}$. Características sociodemográficas y variabilidad geográfica relacionada con la satisfacción del paciente en Atención Primaria. Rev Calid Asist. 2016;31(5):300-8. https://doi.org/10.1016/j.cali.2016.01.004

6. Rahmqvist M, Bara AC. Patient characteristics and quality dimensions related to patient satisfaction. Int J Qual Health Care. 2010;22(2):86-92. https://doi.org/10.1093/intqhc/mzq009

7. Barrasa JI, Aibar C. Revisión sistemática de los estudios de satisfacción realizados en España en el período 1986-2001. Rev Calid Asist. 2003;18(7):580-90. https://doi.org/10.1016/S1134-282X(03)77642-8

8. PricewaterhouseCoopers España. Diez temas candentes de la Sanidad Española para 2013. Para que la crisis económica no se transforme en una crisis de salud pública. Espanha: PWC España; 2013 [citado 15 feb 2019]. Disponible en: https://www.pwc.es/es/publicaciones/sector-publico/ assets/diez-temas-candentes-sanidad-2013.pdf

9. World Health Organization, Regional Office for Europe. European strategic directions for strengthening nursing and midwifery towards Health 2020 goals. Copenhagen (DNK): WHO Regional Office for Europe; 2015 [citado 15 feb 2019]. Disponible en: http://www.euro.who. int/_data/assets/pdf_file/0004/274306/European-strategic-directions-strengthening-nursingmidwifery-Health2020_en-REV1.pdf?ua=1

10. Jefatura del Estado (ESP). Ley 14/1986, de 25 de abril 1986. General de Sanidad. Bol Oficial Estado. 29 abr 1986 [citado 15 feb 2019]. Disponible en: https://www.boe.es/buscar/pdf/1986/BOE-A-1986-10499-consolidado.pdf

11. Jefatura del Estado (ESP). Ley 6/2003, de 28 mayo de 2003. De cohesión y calidad del Sistema Nacional de Salud. Bol Oficial Estado. 29 mayo 2003 [citado 15 feb 2019]. Disponible en: https://www.boe.es/buscar/pdf/2003/BOE-A-2003-10715-consolidado.pdf

12. Fernández-Macías E. Evaluación del proceso de descentralización del Sistema Nacional de Salud desde la perspectiva de los ciudadanos. Salamanca (ESP); Universidad de Salamanca; 2011 [citado 11 oct 2018]. Disponible en: http://www.academia.edu/2865536/Evaluación_ del_proceso_de_descentralización_del_sistemas_nacional_de_salud_desde_la_perspectiva_ de_los_ciudadanos

13. Filippidis FT, Mian SS, Millett C. Perceptions of quality and safety and experience of adverse events in 27 European Union healthcare systems, 2009-2013. Int J Qual Health Care. 2016;28(6):721-7 https://doi.org/10.1093/intqhc/mzw097

14. Ministerio de Sanidad, Servicios Sociales e Igualdad (ESP). Indicadores clave del Sistema Nacional de Salud. Madrid (ESP); 2003 a 2017 [citado 28 mayo 2018]. Disponible en: http://inclasns.msssi.es/main.html

15. Ministerio de Sanidad, Consumo y Bienestar Social (ESP). Portal Estadístico del SNS. Opinión de los ciudadanos: barómetro sanitario 2003 a 2017. Madrid (ES); 2018 [citado 13 2018]. Disponible en: https://www.mscbs.gob.es/estadEstudios/estadisticas/BarometroSanitario/home_BS.htm

16. Kleefstra SM, Zandbelt LC, Haes HJ, Kool RB. Trends in patient satisfaction in Dutch university medical centers: room for improvement for all. BMC Health Serv Res. 2015;15(1):112. https://doi.org/10.1186/s12913-015-0766-7

17. Ministerio de Sanidad, Consumo y Bienestar Social (ESP). Sanidad: profesionales: historia clínica digital del Sistema Nacional de Salud. Madrid (ES); s.d. [citado 11 dic 2018]. Disponible en: https://www.mscbs.gob.es/profesionales/hcdsns/home.htm

18. Batailler P, François P, Dang VM, Sellier E, Vittoz JP, Seigneurin A, et al. Trends in patient perception of hospital care quality. Int J Health Care Qual Assur. 2014;27(5):414-26, https://doi.org/10.1108/IJHCQA-02-2013-0014

19. Nombela-Monterroso K, González-Chordá VM, Roman P. Estudio descriptivo de la Atención Especializada del Sistema Sanitario de España. Rev Saude Publica. 2018;52:5. https://doi.org/10.11606/S1518-8787.2018052000289 
20. Ministerio de Sanidad, Servicios Sociales e Igualdad. (ESP). Informe Anual del Sistema Nacional de Salud 2016. Madrid (ESP); 2016 [citado 15 feb 2019]. Disponible en: https://www.mscbs. gob.es/estadEstudios/estadisticas/sisInfSanSNS/tablasEstadisticas/InfAnualSNS2016/Informe_ Anual_SNS_2016_completo.pdf

21. Bacigalupe A, Martín U, Font R, González-Rábago Y, Bergantiños N. Austeridad y privatización sanitaria en época de crisis: ¿existen diferencias entre las comunidades autónomas? Gac Sanit. 2016;30(1):47-51. https://doi.org/10.1016/j.gaceta.2015.10.003

22. Kraska RA, Weigand M, Geraedts M. Associations between hospital characteristics and patient satisfaction in Germany. Health Expect. 2017;20(4):593-600. https://doi.org/10.1111/hex.12485

23. Pérez Cantó V, Maciá Soler ML, González Chordá VM. Satisfacción de los usuarios en 2 hospitales con diferente modelo de gestión. J Health Qual Res. 2018;33(6):334-42. https://doi.org/10.1016/j.jhqr.2018.07.005

24. Simó J, Gérvas J. Gasto sanitario en atención primaria en España: insuficiente para ofrecer servicios atrayentes para pacientes y profesionales. Informe SESPAS 2012. Gac Sanit. 2012;26 Suppl1:36-40. https://doi.org/10.1016/j.gaceta.2011.05.017

25. Raivio R, Jääskeläinen J, Holmberg-Marttila D, Mattila KJ. Decreasing trends in patient satisfaction, accessibility and continuity of care in Finnish primary health care: a 14-year follow-up questionnaire study. BMC Fam Pract. 2014;15(1):98. https://doi.org/10.1186/1471-2296-15-98

26. Aiken LH, Sermeus W, Van den Heede K, Sloane DM, Busse R, McKee M, et al. Patient safety, satisfaction, and quality of hospital care: cross sectional surveys of nurses and patients in 12 countries in Europe and the United States. BMJ. 2012;344:e1717. https://doi.org/10.1136/bmj.e1717

27. You LM, Aiken LH, Sloane DM, Liu K, He GP, Hu Y, et al. Hospital nursing, care quality, and patient satisfaction: cross-sectional surveys of nurses and patients in hospitals in China and Europe. Int J Nurs Stud. 2013;50(2):154-61. https://doi.org/10.1016/j.ijnurstu.2012.05.003

28. Isaac T, Zaslavsky AM, Cleary PD, Landon BE. The relationship between patients' perception of care and measures of hospital quality and safety. Health Serv Res. 2010;45(4):1024-40. https://doi.org/10.1111/j.1475-6773.2010.01122.x

29. Sack C, Scherag A, Lütkes P, Günther W, Jöckel K-H, Holtmann G. Is there an association between hospital accreditation and patient satisfaction with hospital care? A survey of 37,000 patients treated by 73 hospitals. Int J Qual Health Care. 2011;23(3):278-83. https://doi.org/10.1093/intqhc/mzr011

30. Filippidis FT, Mian SS, Millett C. Perceptions of quality and safety and experience of adverse events in 27 European Union healthcare systems, 2009-2013. Int J Qual Health Care. 2016;28(6):721-7. https://doi.org/10.1093/intqhc/mzw097

31. Nolasco A, Vicent-Castelló EM, Pereyra-Zamora P, Caballero-Pérez P, Moncho J. Mortalidad por complicaciones médicas y quirúrgicas, impacto de la crisis y gasto sanitario en España, 2002-2013. Gac Sanit. 2018. https://doi.org/10.1016/j.gaceta.2018.07.017

Authors' contributions: Conception and planning of the study, data collection, analysis and interpretation of the data: VPC, VMGCH, LMS. Elaboration or revision of the manuscript: VPC, VMGCH. Approval of the final version to be published: VPC, VMGCH, LMS. All authors assume public responsibility for the content of the article.

Conflict of Interest: The authors declare no conflict of interests. 